\title{
Study about concrete with recycled expanded polystyrene
}

\section{Estudo de concreto com poliestireno expandido reciclado}

\author{
C. H. R. CARVALHO \\ carlos.carvalho@ufu.br \\ https://orcid.org/0000-0003-1226-687X \\ L. A. C. MOTTA \\ lacastro@ufu.br \\ https://orcid.org/0000-0002-1597-2297
}

\begin{abstract}
This work studied the properties of lightweight concretes with addition of expanded polystyrene (EPS) for structural walls applications. EPS for being a material produced on a large scale and has low density, produces a large volume of waste. These residues are not reused, especially in Brazil. Given that, in order to perform a comparison of the performance of concrete with adding of EPS in pearls and recycled, it have been manufactured five concrete types, a control without addition of EPS and four other samples with two different percentages of EPS. The mechanical (compressive strength) and physical (density, voids content, absorption by immersion and capillarity) properties were evaluated, and tests were carried out to evaluate the thermal performance of the mixtures studied. The concretes with EPS presented compressive strength less than the reference concrete, however, the absorption for capillarity and thermal properties was better in concretes with EPS. It is concluded that it is feasible to replace the EPS in pearls by recycled EPS, due to the close results found.
\end{abstract}

Keywords: EPS concrete, recycled EPS, structural walls, thermal behavior.

\section{Resumo}

O concreto leve obtido com adição de partículas de poliestireno expandido (EPS) é conhecido como concreto com EPS. Estudaram-se neste trabalho as propriedades de concretos com adição de EPS para uso em paredes estruturais. O EPS por ser um material produzido em larga escala e possuir baixa densidade, produz um grande volume de resíduos. Esses resíduos são pouco reaproveitados, principalmente no Brasil. Diante disso, a fim de realizar uma comparação do desempenho do concreto com a adição de EPS em pérolas e o reciclado, foram fabricados cinco tipos de concretos, o primeiro de controle sem a adição de EPS e os outros quatro com duas porcentagens diferentes de EPS. Foram avaliadas as propriedades mecânicas (resistência à compressão), físicas (massa específica, índice de vazios, absorção por imersão e por capilaridade) e foram realizados testes para avaliar o desempenho térmico das misturas estudadas. Os concretos com EPS apresentaram resistência à compressão inferior ao concreto referência, entretanto, o desempenho quanto à absorção por capilaridade e às propriedades térmicas foi melhor nos concretos com EPS. Conclui-se também que é viável a substituição do EPS em pérolas por EPS reciclado, devido às proximidades nos resultados encontrados.

Palavras-chave: concreto com EPS, EPS reciclado, paredes estruturais, comportamento térmico.

Universidade Federal de Uberlândia, Faculdade de Engenharia Civil, Programa de Pós Graduação em Engenharia Civil, Uberlândia, Brasil. 


\section{Introduction}

Usually, the lightweight concrete designation is used to identify concretes with porous structure, generally based on hydraulic binders, with density lower than traditional concrete, that can be obtained with the use of lightweight aggregates, with the incorporation of air (cellular concrete) or without filler [1].

In addition to the technical and economic issues, the choice of building materials is also based on the environmental aspects of the implementation and use of the materials, in this sense, the lightweight concrete can provide, in its lower density, decreased reinforcement, energy used in transportation and in the constructive process. Due to its ability to heat insulation, it lowers energy consumption in thermal conditioning of buildings, when used in external seals [2].

Yet on this environmental issue, industrialized materials mobilize vast financial resources, consume a huge amount of energy, generate great amounts of waste that in large majority are not reused, causing permanent pollution, besides to the consumption of nonrenewable raw materials.

According to Leite [3], there are many sources that generate waste in construction. For example, the waste of materials that could be reused in construction, but instead, leave the site in form of rubble that contribute in the volume of waste generated. Hence the importance of researching for new materials to manufacture concrete from unconventional methods, mostly recyclable.

Expanded polystyrene (EPS), can fit between these new materials to replace the aggregate in the concrete, in addition to the traditional materials: cement, natural aggregates and water, may contain additives and other additions, including fibers. As the EPS is formed by approximately $95 \%$ to $98 \%$ air, it works pretty much like developer agent of voids.

According to Monteiro [4], in Brazil were produced 55000 tons of EPS in the year 2007 and other 2000 tons were imported with electronic equipment and different goods brought from abroad. In 2008 were produced in Brazil about to 62900 tons of expanded polystyrene (EPS) and about 20000 tons of Extruded Polystyrene (XPS), a thermal insulator normally presented in light and rigid boards, totaling about 82900 tons. Of this total, it is estimated that approximately 7000 tons were returned to the productive process of recycling, that is, only 8.4 percent of everything that was produced. Estimates indicate that the EPS takes about hundreds of years to be completely degraded.

There are studies with the use of EPS in the form of beads, as aggregate for lightweight concrete. In experiments done by Parant and Le Roy [5], to formulate and optimize concretes with expanded polystyrene, the density and the structural strength were changed. The results showed that the compressive strength of concrete with EPS increases with the decrease in the size of the EPS beads for a same density. For example, for concrete with a density of 1000 $\mathrm{kg} / \mathrm{m}^{3}$ and $7 \mathrm{~mm}$ beads, showed a $35 \%$ reduction in compressive strength compared to the same compound, but with $1 \mathrm{~mm}$ polystyrene beads.

This trend of the smaller the diameter of the beads of EPS, the higher the compressive strength of concrete with EPS of the same density, was then confirmed by Ganesh Babu and Saradhi Babu
[6], in a study of concretes with EPS and densities (ranging from $1440 \mathrm{~kg} / \mathrm{m}^{3}$ to $1850 \mathrm{~kg} / \mathrm{m}^{3}$ ) and two sizes of EPS beads: $4.75 \mathrm{~mm}$ and $6.3 \mathrm{~mm}$.

However, EPS can also be reused from waste disposed of, reducing the environmental impact of disposing of this polymer of hard decomposition and even improving the properties of new materials or modified like the lightweight concrete, for example.

The aim of this paper it was to produce mixtures of concrete with EPS beads and recycled EPS particles in order to assess and compare their properties for application in structural walls of buildings. Mechanical, physical properties were evaluated. Small cubicles were also built with EPS concrete slabs containing different amount of EPS to evaluate the effectiveness of the EPS addition in controlling the heat flow and internal temperature

\section{Materials and experimental program}

In accordance to the objectives proposed in this research, the methodology was implemented based on experimental program, in the laboratory, with small slabs simulating the concrete walls. Those boards were designed in such a way that the results could provide information about characterization, from the point of view of thermal performance of concrete walls with EPS.

The EPS used was of two kinds, beads and recycled. In the concrete type $A$, was replaced the entire volume of coarse aggregate (gravel) for the EPS. in the concrete type B, besides the adopted replacement used in concrete type $A$, there was an increase of EPS in partial replacement to the corresponding volume of fine aggregate (sand). The results were compared to concretes without replacement of the gravel by EPS (Reference Concrete).

It was verified the influence of addition of EPS on some properties of concrete using cylindrical specimens of $10 \mathrm{~cm}$ diameter by $20 \mathrm{~cm}$ high. Samples were tested for the determination of compressive strength, density, void ratio, absorption by immersion and capillarity. Consistency and density of fresh concretes have been evaluated. The entire process was conducted in the laboratory in accordance with the Brazilian standards and methods.

The developed experimental program was divided into the following stages: selection and characterization of the material compost of mixtures, study and choice of the proportions, molding of concrete specimens and the concrete slabs, characterization tests of fresh and hardened concrete and thermal test.

\subsection{Materials}

The materials involving the produced concrete are broken down below: - Cement CP V ARI;

- Fine Aggregate (Sand, average 2.42 fineness modulus and density $2.66 \mathrm{~g} / \mathrm{cm}^{3}$ );

- Coarse Aggregate (Crushed stone of basalt rock, granulometry $4.75 / 12.5 \mathrm{~mm}$, density $2.88 \mathrm{~g} / \mathrm{cm}^{3}$ );

- Water from the public supply network;

- Superplasticizing admixture MasterGlenium 3400 of BASF;

Recycled EPS and beaded.

The CPV cement was used as the type of cement most used in buildings of concrete-walls, due to the need to remove the 
Table 1

Details of mixtures to produce $1 \mathrm{~m}^{3}$ of concrete

\begin{tabular}{ccccccc}
\hline $\begin{array}{c}\text { Materials } \\
\text { concretes }\end{array}$ & $\begin{array}{c}\text { Cement CP V } \\
(\mathrm{kg})\end{array}$ & $\begin{array}{c}\text { Sand } \\
(\mathrm{kg})\end{array}$ & $\begin{array}{c}\text { Gravel } \\
(\mathrm{kg})\end{array}$ & $\begin{array}{c}\text { EPS } \\
(\mathrm{kg})\end{array}$ & Water(kg) & $\begin{array}{c}\text { Hiperplastificant } \\
(\mathrm{kg})\end{array}$ \\
\hline CR & 500 & 1050 & 1210 & 0 & 200 & 5 \\
CAP & 500 & 1050 & 0 & 6.5 & 200 & 5 \\
CAR & 500 & 1050 & 0 & 5.2 & 200 & 5 \\
CBP & 500 & 864 & 0 & 7.7 & 200 & 5 \\
CBR & 500 & 864 & 0 & 6.0 & 200 & 5 \\
\hline
\end{tabular}
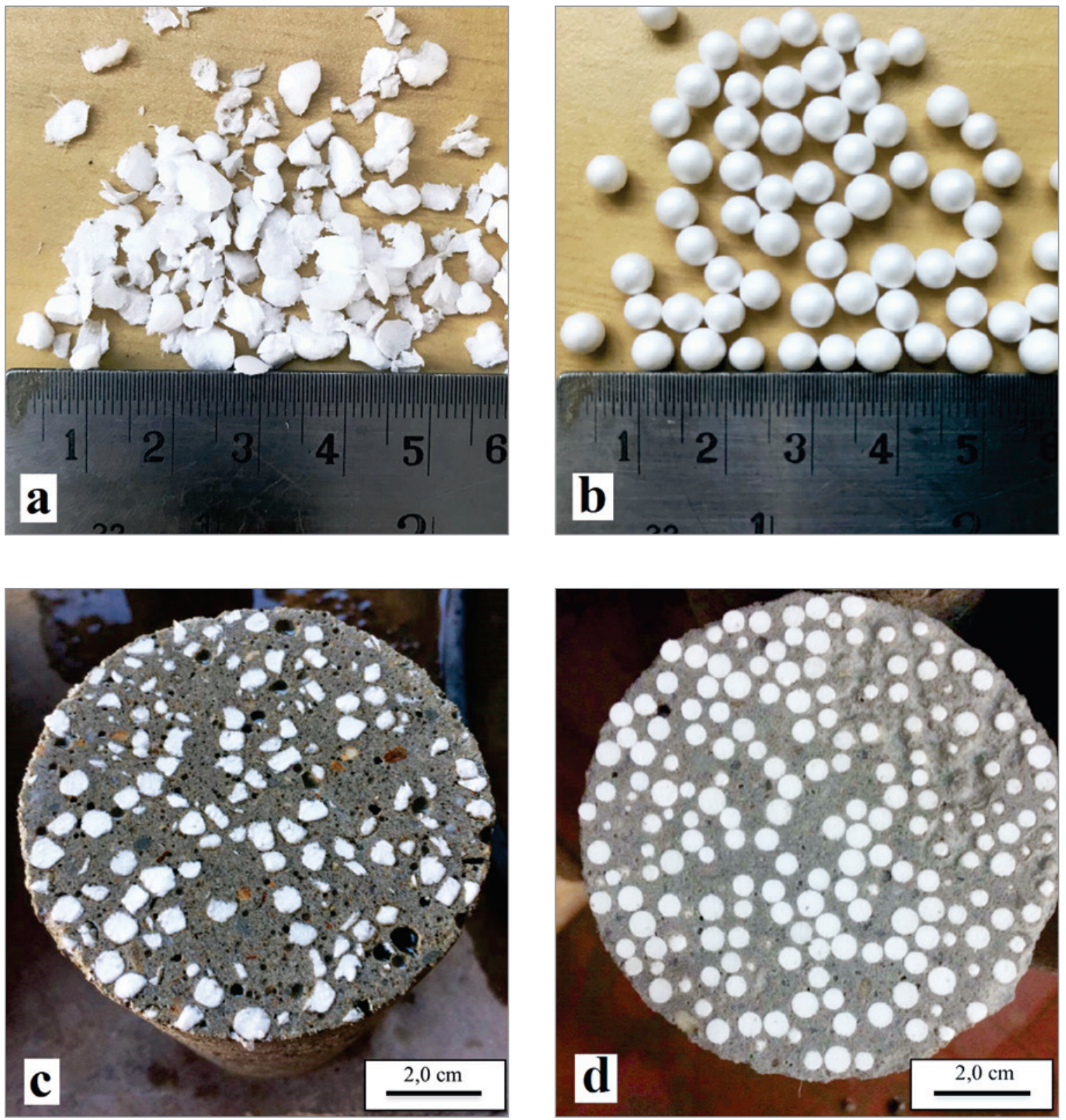

Figure 1

Recycled EPS particles (1a) and EPS pearls (1b), concrete with recycled EPS (1c) and concrete with EPS pearls (1d) 


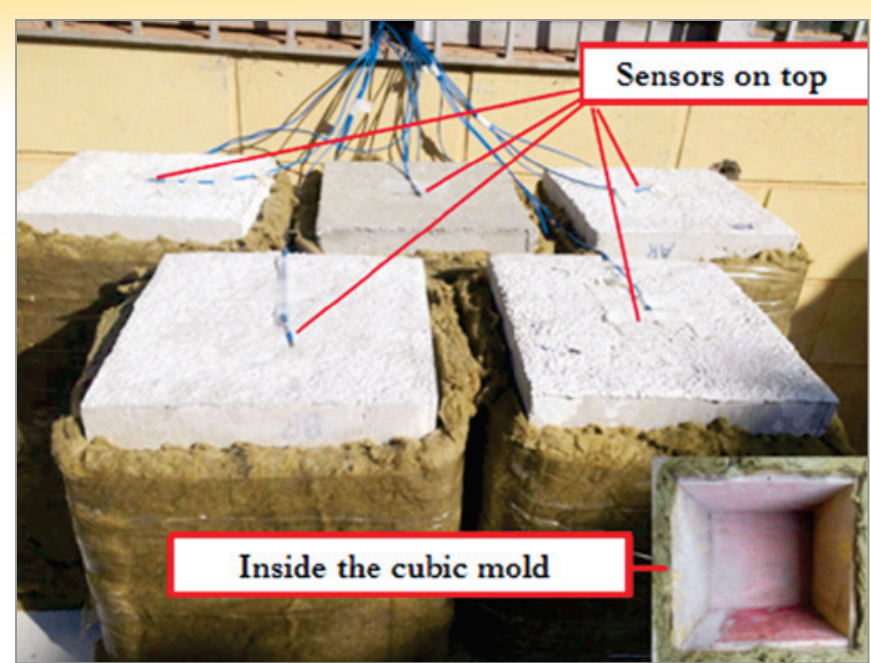

Figure 2

System of plywood molds with slabs of 5 types of concrete

concrete forms quickly. Both the beads and the recycled EPS particles have diameters ranging from 1.2 to $4.8 \mathrm{~mm}$. The two types of EPS have slightly different densities, the EPS in beads has density of $15.5 \mathrm{~kg} / \mathrm{m}^{3}$ and the recycled $12.3 \mathrm{~kg} / \mathrm{m}^{3}$.

The recycled EPS was acquired crushed, however as the particle size were larger than the given to the production of concretes (greater than $4.8 \mathrm{~mm}$ ), It was held new grinding and was subsequently sifting the particles with size varying between 1.2 and 4.8 $\mathrm{mm}$. The EPS in beads was purchased at stationery stores and didn't need screening, because their particles already were in the desired range between 1.2 to $4.8 \mathrm{~mm}$.

\subsection{The concrete production}

Table 1 presents the consumption of concrete materials used in this research. The levels of EPS, replacing the volume of gravel and/or sand, were adopted based on researches already carried out [7] aiming at dosages applicable for concrete walls, with concrete slump test above $160 \mathrm{~mm}$.

The following presents the nomenclature adopted for each type of concrete:

- CR: Reference concrete;

- CAP: Concrete type A, with addition of EPS pearls, replacing the total volume of coarse aggregate (gravel);

- CAR: Concrete type A, with addition of recycled EPS, replacing the total volume of coarse aggregate (gravel);

- CBP: Concrete type B, with EPS pearls incremented, replacing the total volume of coarse aggregate (gravel) and the volume of 70 liters, representing $17.7 \%$ of the original volume of fine aggregate (sand);

- CBR: Concrete type B, with addition of recycled EPS, replacing the total volume of coarse aggregate (gravel) and the volume of 70 liters, representing $17.7 \%$ of the original volume of fine aggregate (sand).

Despite the EPS being of a low-density material, it presented easy handling and good dispersion in the concrete, so the concrete with EPS can be produced from the conventional way in concrete mixer.

The Figure 1 shows recycled EPS particles (1a) and EPS pearls (1b), as well as the concretes produced by them, concrete with recycled EPS (1c) and concrete with EPS pearls (1d).

\subsection{Tests of fresh concrete}

After the mixture were executed the concrete slump test, for the evaluation of the consistency and the test for the determination of density of fresh concrete, according to ABNT NBR NM 67:1998 and ABNT NBR 9833:2008, respectively.

\subsection{Tests of hardened concrete}

All experiments were held to 28 days with cylindrical specimens of $10 \mathrm{~cm}$ diameter and $20 \mathrm{~cm}$ of height for every concrete type cured by immersion in water until the day of the tests. The concretes in the hardened state were tested to determine the compressive strength, density, void ratio and absorption by immersion and capilarity, according to ABNT NBR 5739:2007, ABNT NBR 9778:2005 and ABNT NBR 9779:2012, respectively.

\subsection{Thermal test}

To evaluate the thermal performance through the heat flow has been adapted the test proposed by Shadnia, et al. [8], were produced five plywood cubic molds, with dimensions of $(30 \mathrm{~cm} \times 30$ $\mathrm{cm} \times 30 \mathrm{~cm}$ ). At the top of each of the five compartments was placed a slab $\left(30 \times 30 \mathrm{~cm}^{2}\right)$, with $5 \mathrm{~cm}$ of thickness of all types of concrete, the reference (CR), with EPS pearls (CAP and CBP) and recycled (CAR and CBR), as shown in Figure 2.

Cubic moulds were involved with rockwool insulation. Finally, three temperature sensors (thermocouples type K) were installed on each cubicle, two self-adhesive sensors at the center of the top and bottom surfaces of the slabs and another inside the cubicle as shown in Figure 3. These sensors will be simply named top, bottom and inside sensors, respectively, in the discussion later.

The five samples were placed in a space without shadows or obstructions on a sunny day. After connecting all sensors to a data acquisition system, temperatures were recorded for 24 hours starting at 6:00 in the morning. The temperatures were measured every 50 seconds and stored in a data acquisition system.

This procedure had as purpose to analyze the difference in heat between the 3 thermocouple of each sample and evaluate the

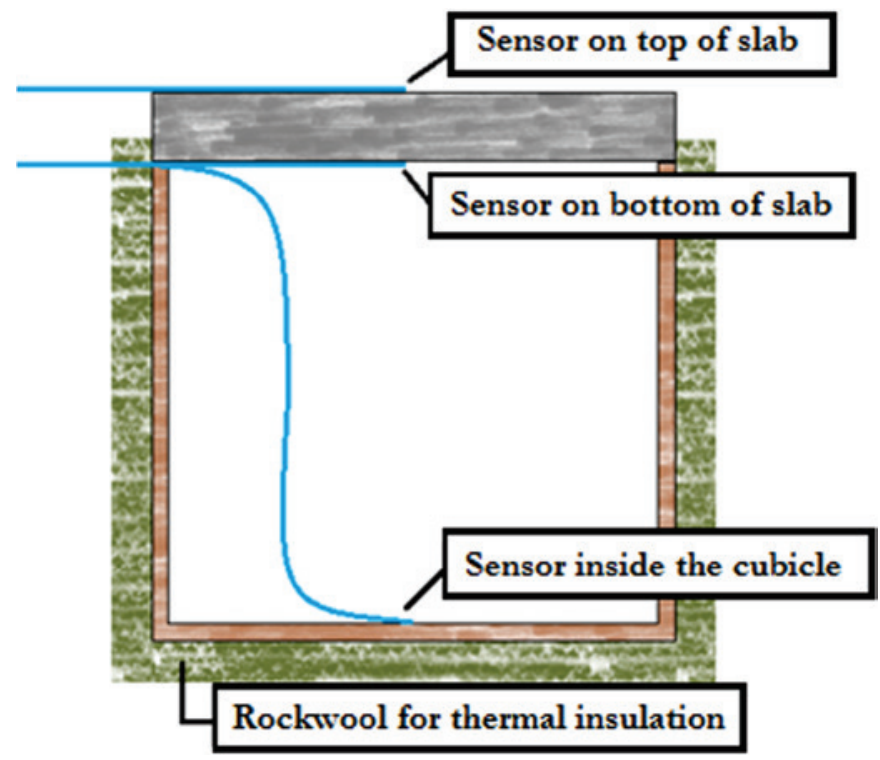

Figure 3

Perspective view of the system 
Table 2

Slump test and density results from fresh concrete

\begin{tabular}{ccc}
\hline $\begin{array}{c}\text { Properties } \\
\text { concretes }\end{array}$ & $\begin{array}{c}\text { Slump test } \\
(\mathbf{m m})\end{array}$ & $\begin{array}{c}\text { Density } \\
\left(\mathbf{g} / \mathbf{c m}^{3}\right)\end{array}$ \\
\hline CR & 170 & 2.32 \\
CAP & 215 & 1.74 \\
CAR & 220 & 1.70 \\
CBP & 225 & 1.65 \\
CBR & 230 & 1.59 \\
\hline
\end{tabular}

effect of the increase in EPS mixtures related to the variation of temperatures and heat flow to inside of the boxes.

\section{Results and discussions}

\subsection{Tests on fresh concrete}

It was possible to observe important features such as homogeneity of the mixture; absence of segregation or EPS floating and absence of bleeding in fresh concrete. In addition to the slump test, it was also evaluated the density of fresh concrete, the results can be seen in Table 2.

It was observed that when you add the EPS in concrete, either through beads or recycled, the measured slump increases, which can be explained due to the replacement of the EPS have been made for added volume, because as the EPS is not a hygroscopic material, that means doesn't absorb water, more free water remained in the system which in turn increased the slump. According to Catoia [9] the concrete with EPS, being composed of mortar and EPS beads, presents typically a flow greater than a conventional concrete.

In relation to densities, the concretes with EPS were obviously lighter than conventional concrete, but when compared to each other, the concretes with beaded EPS showed slightly higher density to the respective proportions concrete with recycled EPS, this fact can be explained, because as already demonstrated the density of the EPS in beads is greater than the recycled EPS.

\subsection{Tests on hardened concrete}

\subsubsection{Compressive strength}

As described earlier the test was held to 28 days. In Table 3 are the average results of resistances evaluated.

It was noted that the increase of EPS contributed in a negative

\section{Table 3}

Average values and standard deviation of the compressive strength of the concretes

\begin{tabular}{cc}
\hline Properties concretes & $\begin{array}{c}\text { Compressive strength } \\
\text { (MPa) }\end{array}$ \\
\hline CR & $23.16(0.56)$ \\
CAP & $15.07(0.52)$ \\
CAR & $14.04(0.46)$ \\
CBP & $12.88(0.49)$ \\
CBR & $11.38(0.54)$ \\
\hline
\end{tabular}

way to the strength of concrete, the concretes with EPS beads presented a slightly superior strength than the concrete with recycled EPS, this is probably because the EPS in beads has a more rigid structure than the recycled, proven by its greater density. The concretes of type A (CAP and CAR), presented greater strength compared to concretes of type $B$ (CBP and $C B R$ ), which was to be expected, given the concretes of type $B$ presents a larger volume of EPS than type A.

The concretes with EPS not reached the compressive strength of $20 \mathrm{MPa}$, minimum established by ABNT NBR 6118:2014 for structural purposes. However, it is known that the maximum request to compression in family residence buildings in concrete walls is less than $1 \mathrm{MPa}$. In addition, it must be possible to adjust a concrete with EPS with compressive strength of $20 \mathrm{MPa}$, reducing the amount of EPS, or decreasing the water/cement ratio used in developed mixtures since the insertion of EPS improved the flow of fresh concrete.

\subsubsection{Density, absorption by immersion and void ratio}

The tests for the determination of density, water absorption by immersion and void ratio were held to 28 days. The results can be seen in Table 4, where it may be noted that both the presence as enhancing EPS increased absorption and voids content and reduced density in relation to the reference concrete.

This was due to the trend of incorporating more air for the mixture to add EPS in concretes. This increased the absorption and the porosity. That observation was repeated in all the concretes with EPS in beads or recycled.

The addition of the EPS in beads resulted in greater absorption and voids ratio than the concretes with recycled EPS, the CBP concrete presented the greatest absorption of $18.16 \%$ and the highest percentage of voids of $27.34 \%$. This fact can be explained due to the concrete type B having a higher amount of EPS in its constitution. The concretes with beads presented more voids content, probably due to the spherical shape and its uniform particle size composition which may have disadvantaged the particles grouping.

In relation to density the concretes showed the same trend of this property in the fresh state, the decrease of density with increasing of EPS in mixtures, reaching $33 \%$ reduction. All the concretes with EPS can be classified as lightweight according to ABNT NBR 8953:2015, which classifies a lightweight concrete with density less than $2.0 \mathrm{~g} / \mathrm{cm}^{3}$.

\section{Table 4}

Average values and standard deviation of the water absorption by immersion, void ratio and density of the studied concretes

\begin{tabular}{cccc}
\hline $\begin{array}{c}\text { Properties } \\
\text { concretes }\end{array}$ & $\begin{array}{c}\text { Absorption } \\
(\%)\end{array}$ & $\begin{array}{c}\text { Void ratio } \\
(\%)\end{array}$ & $\begin{array}{c}\text { Density } \\
\left(\mathrm{g} / \mathrm{cm}^{3}\right)\end{array}$ \\
\hline CR & $8.83(0.67)$ & $17.66(1.37)$ & $2.24(0.06)$ \\
CAP & $16.30(0.71)$ & $25.56(0.94)$ & $1.66(0.11)$ \\
CAR & $15.30(0.98)$ & $24.14(1.64)$ & $1.62(0.09)$ \\
CBP & $18.16(0.93)$ & $27.34(1.23)$ & $1.56(0.10)$ \\
CBR & $13.98(0.27)$ & $21.21(0.97)$ & $1.50(0.08)$ \\
\hline
\end{tabular}




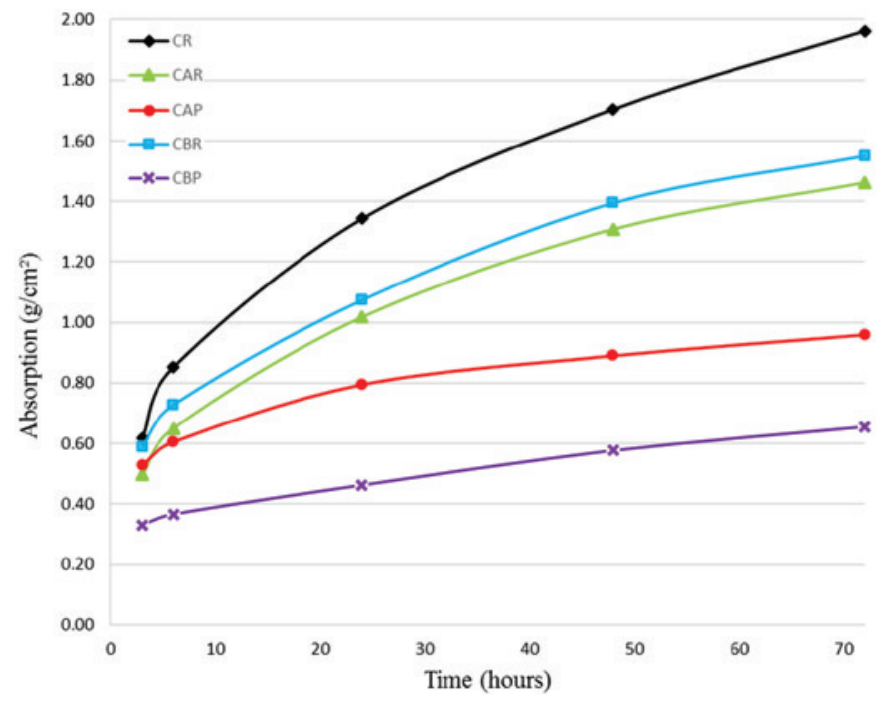

Figure 4

Absorption by capillarity results

\subsubsection{Absorption by capillarity}

The test for evaluation of absorption for capillarity was held at 28 days, the values of water absorption for capillarity (C) obtained after 3, 6, 24, 48 and 72 hours of partial immersion can be found in Figure 4.

Contrary to what was observed in the test of absorption by immersion, the concrete with greater water absorption by capillarity was the reference concrete and concrete with lower water absorption by capillarity was the concrete type $B$ with beads (CBP). It is observed according to the results a trend of EPS, especially in higher levels, cause a decrease of capillary absorption. Evaluating the absorption 72 hours after partial immersion in water the addition, EPS in beads demonstrated greater efficacy in reducing absorption for capillarity, the CBP concrete presented a $66.3 \%$ reduction and the concrete CAP presented a decrease of $51.0 \%$ compared the reference concrete. The concrete with recycled EPS showed a considerable reduction, but smaller than the concretes with EPS in beads, the concrete CAR presented a decrease of $25.5 \%$ and concrete CBR presented a $20.9 \%$ reduction relative to the reference concrete.

After the last weighing the specimens were broken down for the measurement of the height of rising capillarity. Follow the rising capillarity values largest to smallest value: $C R(9.52 \mathrm{~cm}), \mathrm{CBR}$ (8.12), CAR $(7.46 \mathrm{~cm}), \mathrm{CAP}(6.82 \mathrm{~cm})$ and CBP $(4.27 \mathrm{~cm})$.

According to Helene [10] the capillary absorption is the most common and intense aggressive agents penetration into concrete. Still according to the same author absorption by capillarity is one of the most difficult factors to be controlled because concrete is a hydrophilic material (has great affinity with water). The smaller the diameter of the capillary pores, greater capillary pressures developed and consequently the greater the depth of concrete met by water absorbed. However the greater the diameter of these capillary pores the less is the depth, but greater the amount of water absorbed. Although more important than the size of these capillaries is the interconnectivity between them.

The presence of the EPS increased porosity and the total absorption of the concretes, but on the other hand seems to have generated pores larger and/or decreased the interconnection between these pores, thus reducing capillary pressures and hence the absorption by capillarity.

In order to minimize the effect of absorption, Mostardeiro [11] and Barin [12] suggest that the capillary absorption can be controlled with use air-entraining agent, which allow the disrupt communication between

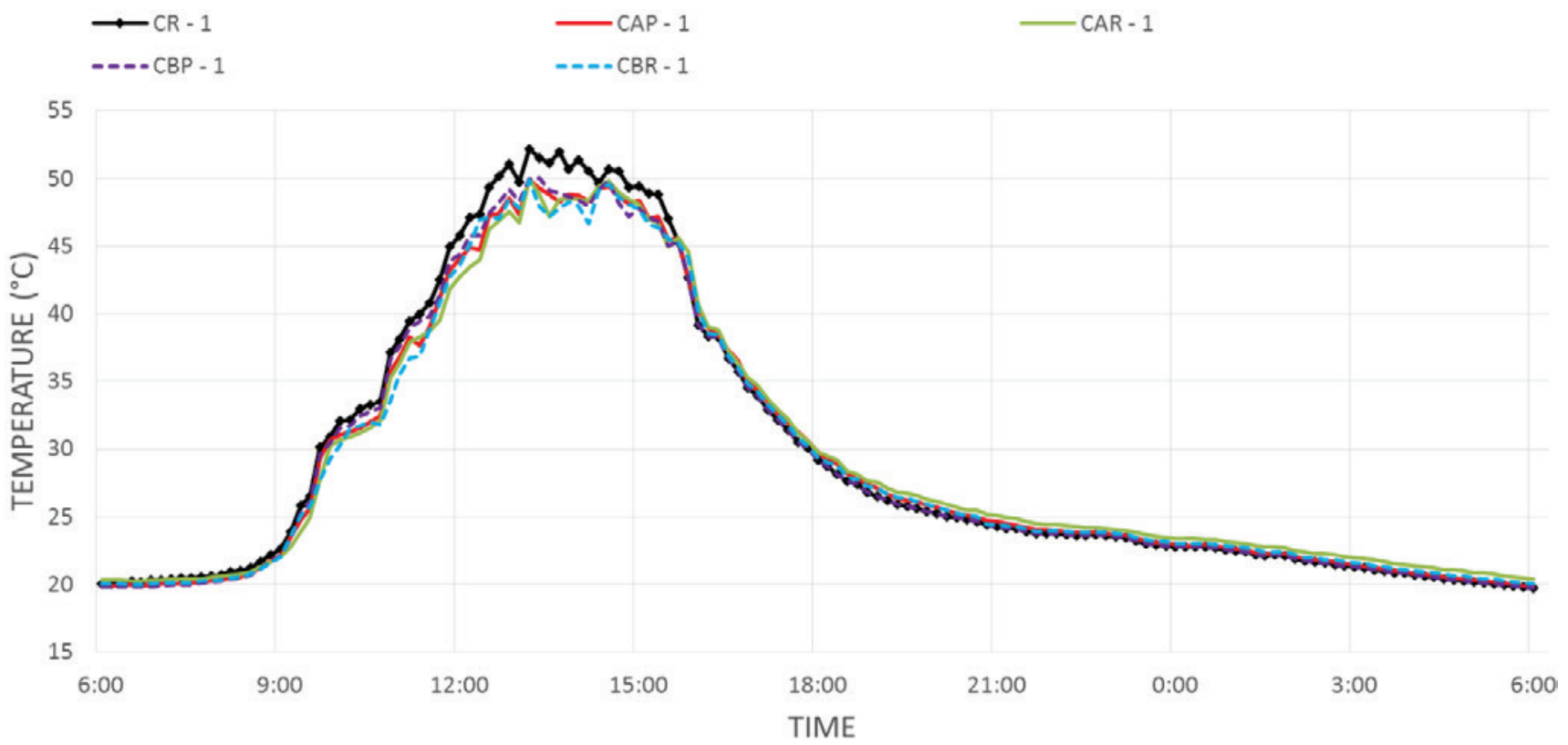

Figure 5

Temperatures of sensors on top of slabs 


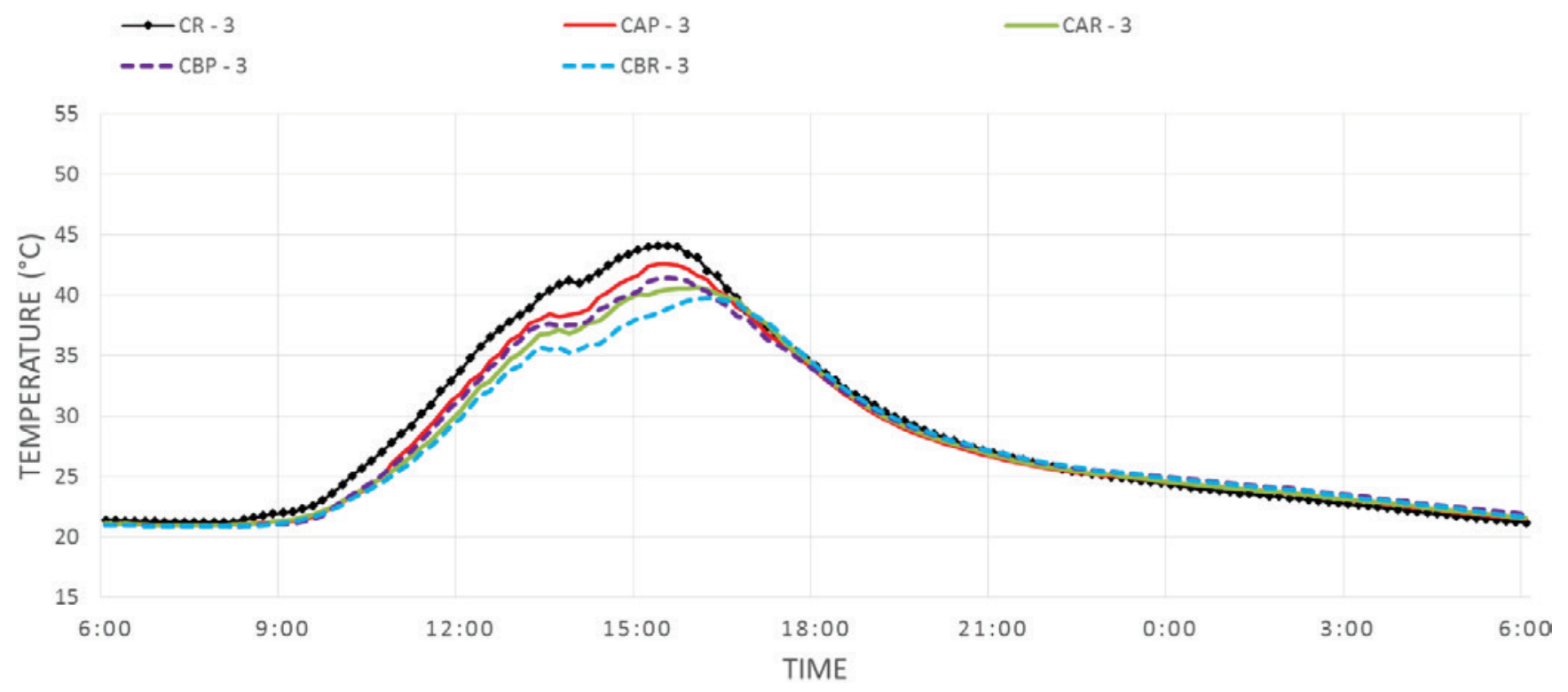

\section{Figure 6}

Temperatures of sensors on bottom of slabs

the pores by the incorporation of tiny air bubbles in its interior, reducing the capillarity in the system.

Therefore, as the EPS is waterproof and acts as an air-entraining agent in concrete, that allow these air bubbles inside of mixtures disrupt communication between the capillary pores.

\subsubsection{Thermal test}

To facilitate the understanding and analysis of the results the sen- sor on top of slabs was named (1), the sensor on bottom of slabs named (2) and the sensor inside the compartment (3). For example, the sensor inside the compartment of reference concrete was named CR-3.

Figures 5, 6 and 7 show, respectively, the temperatures on top of slabs, on bottom of slabs and inside the compartment, measured during 24 hours for the five samples.

Figure 6 indicates that the temperature on bottom of slabs containing any type of EPS start rising a few minutes later than the

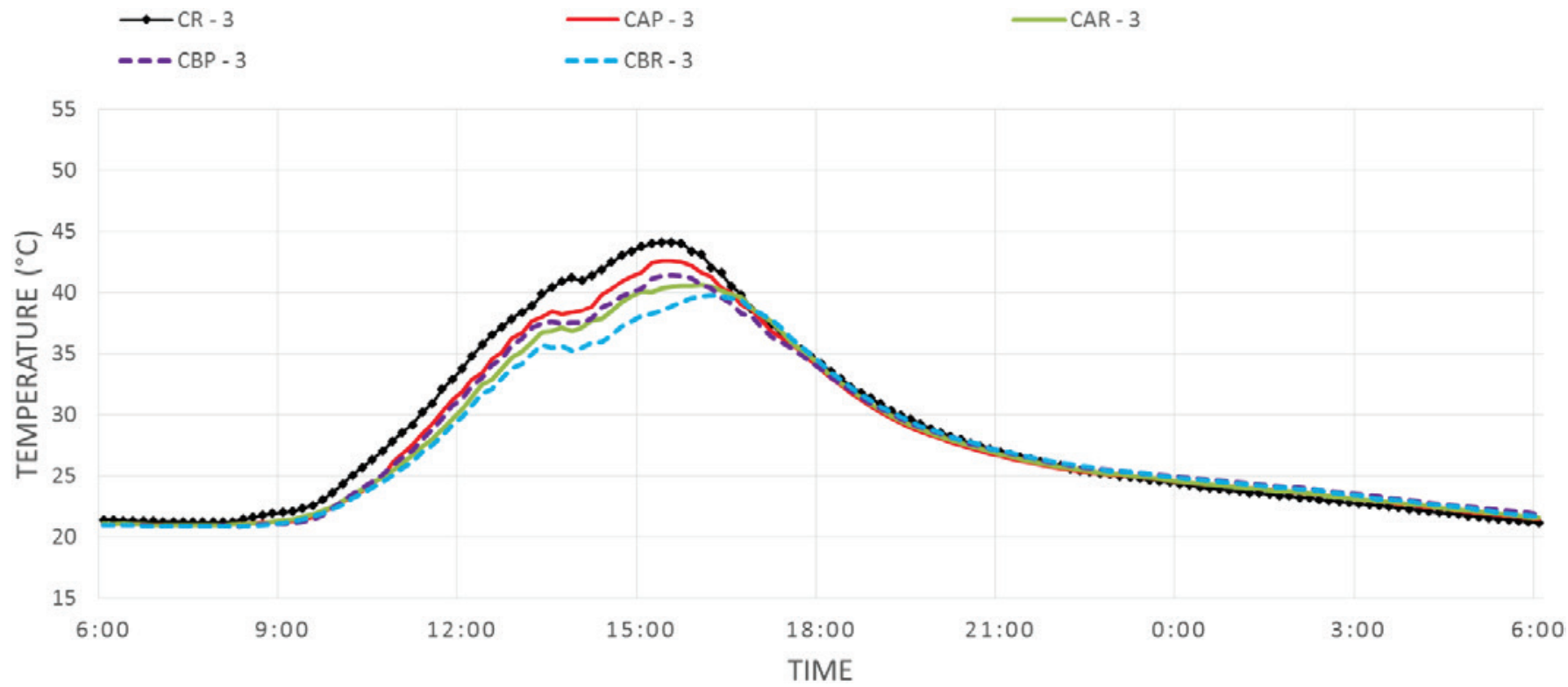

Figure 7

Temperatures of sensors inside of the compartment 
Table 5

Correlation between the highest temperature and the respective time

\begin{tabular}{ccc}
\hline Sensor & $\begin{array}{c}\text { Highest temp. } \\
\left({ }^{\circ} \mathrm{C}\right)\end{array}$ & Time \\
\hline CR - 1 & 52.16 & $1: 10 \mathrm{PM}$ \\
CR - 2 & 48.71 & $3: 00 \mathrm{PM}$ \\
CR - 3 & 44.13 & $3: 30 \mathrm{PM}$ \\
CAP - 1 & 49.86 & $1: 10 \mathrm{PM}$ \\
CAP - 2 & 46.60 & $3: 10 \mathrm{PM}$ \\
CAP - 3 & 42.60 & $3: 30 \mathrm{PM}$ \\
CAR - 1 & 49.92 & $1: 10 \mathrm{PM}$ \\
CAR - 2 & 46.21 & $3: 10 \mathrm{PM}$ \\
CAR - 3 & 40.62 & $4: 00 \mathrm{PM}$ \\
CBP - 1 & 49.98 & $1: 20 \mathrm{PM}$ \\
CBP - 2 & 46.41 & $3: 10 \mathrm{PM}$ \\
CBP - 3 & 41.40 & $3: 30 \mathrm{PM}$ \\
CBR - 1 & 49.84 & $1: 10 \mathrm{PM}$ \\
CBR - 2 & 45.31 & $3: 10 \mathrm{PM}$ \\
CBR - 3 & 39.75 & $4: 10 \mathrm{PM}$ \\
\hline
\end{tabular}

reference concrete slab. During the period of increased temperature of 8:00 am to $3: 00 \mathrm{pm}$ the temperatures on bottom of the EPS slabs were on average of $1.6^{\circ} \mathrm{C}$ to $2.9^{\circ} \mathrm{C}$ lower than the slab without EPS, with the largest temperature difference $\left(4.7^{\circ} \mathrm{C}\right)$ happened at 1:40 pm between the sensor on bottom of slab of reference concrete (CR-2) and the same sensor of the concrete type $B$ with recycled EPS (CBR-2).

Obviously, because they have a higher EPS content, the time it takes to raise the temperature takes longer for type B concretes than type A concretes. It can also be seen that after the temperature peaks, the time it takes for the temperature starts to fall is slightly slower with EPS increase. Thus, the EPS well perform the function of attenuating the variation in the internal temperature, due to the change in temperature outside of the compartment.

The measured temperatures inside the compartments show trends similar to those on bottom of slabs, as can be seen in Figure 7 .

During the period of increased temperature from 8:00 am to 3:00 $\mathrm{pm}$, the air temperature inside the compartments containing EPS ranged around $1.8^{\circ} \mathrm{C}$ to $3.6^{\circ} \mathrm{C}$ lower than the reference concrete compartment. The largest temperature difference happened to 2:30 pm between the sensor inside the compartment of the reference concrete (CR-3) and the sensor inside the compartment of type $\mathrm{B}$ concrete with recycled EPS (CBR-3) at a value of $6.0^{\circ} \mathrm{C}$. About the time delay of the temperature rising, the concretes with recycled EPS (CAR and CBR) were more effective than concrete with EPS beads (CAP and CBP), mainly the CBR which exhibited a delay of up to 60 minutes in relation to the reference concrete. Table 6 shows a correlation between the highest temperature and time when it occurred to each of the sensors.

Analyzing the results of Table 6 is very clear that the incorporation of EPS influenced on temperature decrease and the time delay of the temperature rising, especially in type $B$ concrete with recycled EPS (CBR).

\section{Conclusions}

The addition of the EPS resulted in a decrease of the compressive strength of the concretes investigated, reaching approximately $40 \%$ of reduction for type A concretes and approximately $50 \%$ for type B concretes, compared to the reference concrete.

The absorption by immersion and void ratio increased in all mixtures with the addition of EPS. However, the absorption for capillarity reduced with the replacement of mineral aggregates by EPS, reaching a reduction of $66.33 \%$ as compared to the reference concrete, probably because of the tendency of the EPS, especially in higher levels, provide the larger pores, and decrease the interconnection between the capillary pores, thus reducing capillary pressures and hence the absorption by capillarity.

The thermal tests showed that all concretes with EPS proved to be more effective in reduce the temperature than the reference concrete. The best performance was of concrete with highest content of recycled EPS (CBR) that presented a fall of up to $6.0^{\circ} \mathrm{C}$ in its interior the compartment compared to reference concrete.

From this research, proposed dosage studies with other levels and dimensions of particles of EPS to improve the mechanical properties and microstructure analyses of EPS concrete, evaluating, among others, the distribution and pore dimensions in order to better understand the behavior of these materials.

\section{References}

[1] Rossignolo, J. A. Concreto leve de alto desempenho modificado com SB para pré-fabricados esbeltos: dosagem, produção, propriedades e microestrutura. 2003. 220 f. Tese (Doutorado em Ciências e Engenharia de Materiais) - Escola de Engenharia de São Carlos, Universidade de São Paulo, São Carlos, 2003.

[2] ROSSIGNOLO, J. A.; AGNESINI, M. V. C. Concreto estrutural leve. In: ISAIA, G. C. Concreto: ensino, pesquisa e realizações, vol. 2. 793p á 1579p. 2005.

[3] LEITE, B. M. Avaliação de propriedades mecânicas de concretos produzidos com agregados reciclados de resíduos de construção e demolição. 2001 Tese (Doutorado em Engenharia Civil) - Universidade Federal do Rio Grande do Sul, Porto Alegre, 2001.

[4] MONTEIRO, M. A. et al. Plano de gerenciamento integrado de resíduos de isopor - PGIRI. Belo Horizonte - Minas Gerais. Fundação Estadual do Meio Ambiente: Fundação Israel Pinheiro, 2011. 52 p.

[5] PARANT, E.; LE ROY, R. Optimisation des bétons de densité inférieure à 1 . Tech. rep., Laboratoire Central des Ponts et Chaussées, Paris, France, 1999.

[6] BABU, K.G., BABU, D.S.: Behaviour of lightweight expanded polystyrene concrete containing silica fume. Cem. Concr. Res. 2249, 1-8, 2002.

[7] OZÓRIO, B. P. M. Concreto leve com pérolas de EPS: estudo de dosagens e de características mecânicas. 2016. 154p. Tese de Doutorado - Programa de Pós-Graduação em Engenharia Civil (Engenharia de Estruturas) e Área de Concentração em Estruturas - Escola de Engenharia de São Carlos da Universidade de São Paulo, São Carlos, 2016. 
[8] SHADNIA, R. et al. Experimental study of geopolymer mortar with incorporated PCM. Construction and building materials, v. 84, p. 95-102, 2015.

[9] CATOIA, T. Concreto Ultraleve estrutural com pérolas de EPS: Caracterização do material e estudo de sua aplicação em lajes. Tese de doutorado em Engenharia de Estruturas, Escola de Engenharia de São Carlos, Universidade de São Paulo, São Carlos, São Paulo, 2012.

[10] HELENE, P. R. do L. Contribuição ao estudo da corrosão em armaduras de concreto armado. Tese (Livre-Docência) - Escola Politécnica da Universidade de São Paulo, São Paulo, 1993.

[11] MOSTARDEIRO, C. Z. Absorção capilar e resistividade elétrica de concretos compostos com cinza de casca de arroz de diferentes teores de carbono grafítico. Santa Maria, 2011, 165 p. Dissertação (Mestrado em Engenharia Civil) - Universidade Federal de Santa Maria, Santa Maria, 2011.

[12] BARIN, D. S. Carbonatação e absorção capilar em concretos de cimento Portland branco com altos teores de adição de escória de alto forno e ativador químico. Santa Maria, 2008, 171 p. Dissertação (Mestrado em Engenharia Civil) Universidade Federal de Santa Maria, Santa Maria, 2008. 